\title{
Assessment of Codes and Standards Applicable to a Hydrogen Production Plant Coupled to a Nuclear Reactor
}

\author{
M.J. Russell \\ June 2006
}

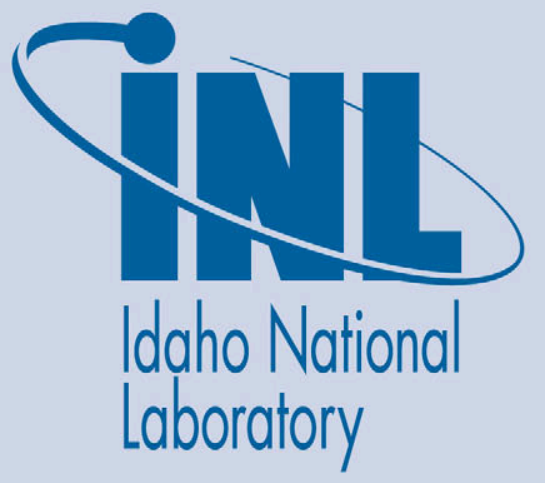

The INL is a U.S. Department of Energy National Laboratory operated by Battelle Energy Alliance 
INL/EXT-06-11482

\title{
Assessment of Codes and Standards Applicable to a Hydrogen Production Plant Coupled to a Nuclear Reactor
}

\author{
M.J. Russell
}

June 2006

Idaho National Laboratory
Idaho Falls, Idaho 83415

Prepared for the

U.S. Department of Energy

Office of Nuclear Energy, Science, and Technology

Under DOE Idaho Operations Office

Contract DE-AC07-05ID14517 


\section{ABSTRACT}

This is an assessment of codes and standards applicable to a hydrogen production plant to be coupled to a nuclear reactor. The result of the assessment is a list of codes and standards that are expected to be applicable to the plant during its design and construction. 



\section{ACKNOWLEDGMENTS}

Thanks to Gail Willmore of the Idaho National Laboratory (INL)

Technical Library for her help in standardizing and making current, the list of standards offered in this document. Thanks to Dave Jenkins of the INL Fossil

Energy Department, for his help in identifying documents that contain permitting requirements. Thanks to Ron Bone of The Idaho Cleanup Project's

Environmental Project Support for his help in condensing an initial diverse list of detailed permitting requirements into a concise, recognizable form. 



\section{CONTENTS}

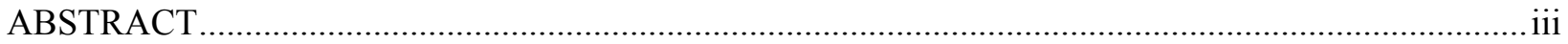

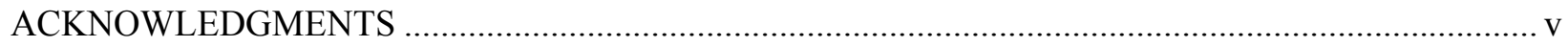

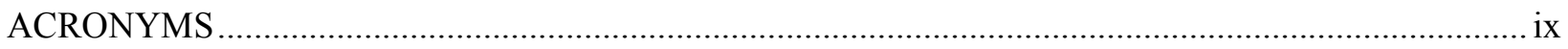

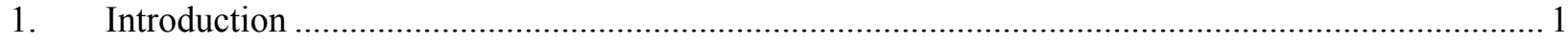

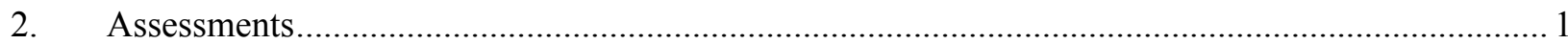

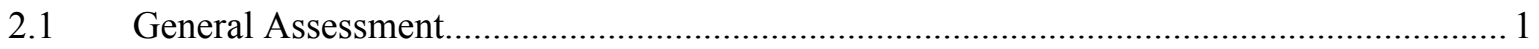

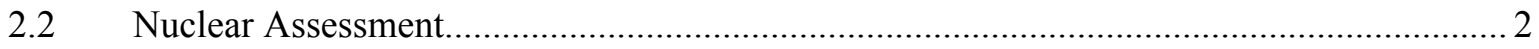

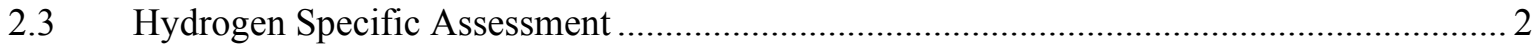

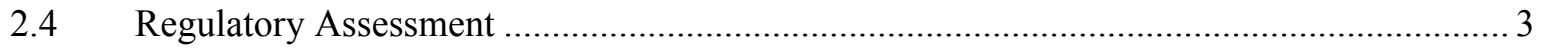

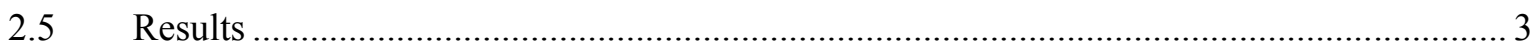

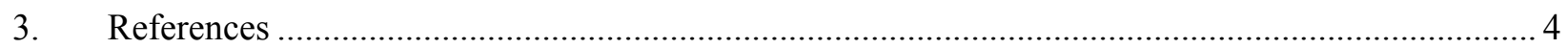

TABLES

1. List of codes and standards applicable to a hydrogen production plant coupled to a nuclear reactor. 



\section{ACRONYMS}

AASHTO American Association of State Highway and Transportation Officials

ACI American Concrete Institute

AIAA American Institute of Aeronautics and Astronautics

AISC American Institute of Steel Construction

AISI American Iron and Steel Institute

ANL Argonne National Laboratory

ANSI American National Standards Institute

API American Petroleum Institute

ARMA Asphalt Roofing Manufacturers Association

ASCE American Society of Civil Engineers

ASME American Society of Mechanical Engineers

ASD Allowable Stress Design

ASHRAE American Society of Heating, Refrigerating, and Air-Conditioning Engineers

ASME American Society of Mechanical Engineers

AWS American Welding Society

AWWA American Waterworks Association

CAA Clean Air Act / Air Programs

CERCLA Comprehensive Environmental Response, Compensation, and Liability Act

CFR Code of Federal Regulations

CGA Compressed Gas Association

CMAA Crane Manufacturers Association of America

DCID Director of Central Intelligence Directive

DM Design Manual

DOE Department of Energy 
EJMA Expansion Joint Manufacturers Association

ERDA Energy Research and Development Administration

HEPA High Efficiency Particulate Air

IAPMO International Association of Plumbing and Mechanical Codes

ICBO International Conference of Building Officials

ICEA Insulated Cable Engineers Association

IDAPA Idaho Administrative Procedures Act

IEEE Institute of Electrical and Electronics Engineers

IES Illuminating Engineering Society

IESNA Illuminating Engineering Society of North America

IFC International Fire Code

IMC International Mechanical Code

INEEL Idaho National Engineering and Environmental Laboratory

INL Idaho National Laboratory

IPC International Plumbing Code

ISA A nonprofit automation and controls organization, http://www.isa.org.

ISDSI Insulated Steel Door Systems Institute

ksi Kips per Square Inch

LRFD Load and Resistance Factor Design

LWP Laboratory-wide Procedure

MBMA Metal Building Manufacturers Association

MSS Manufacturers Standardization Society

NAVFAC Naval Facilities

NBS National Bureau of Standards

NEMA National Electrical Manufacturers Association

NEPA National Environment Policy Act 
NESC National Electrical Safety Code

NFPA National Fire Protection Agency

NISP National Industrial Security Program

NISPOM National Industrial Security Program Operating Manual

NRCA National Roofing Contractors Association

OSHA Occupational Safety and Health Administration

RCRA Resource Conservation Recovery Act

SDI Steel Deck Institute

SDI Steel Door Institute

SEI Structural Engineering Institute

SJI Steel Joist Institute

SMACNA Sheet Metal and Air Conditioning Contractors' National Association

SPRI Single Ply Roofing Industry

TSCA Toxic Substance Control Act

UBC Uniform Building Code

UL Underwriters Laboratory 


\section{Assessment of Codes and Standards Applicable to a Hydrogen Production Plant Coupled to a Nuclear Reactor}

\section{Introduction}

This is an assessment of codes and standards applicable to a hydrogen production plant to be coupled to a nuclear reactor. Functional requirements for such a plant have already been described (Ward, 2006; Argonne National Laboratory - West, 2004). Relevant codes and standards, for both the nuclear and non-nuclear regulatory regimes applicable to permitting, design, and construction were considered. Requirements for operations were not considered given that significant development of the design will be needed before such consideration is meaningful.

\section{Assessments}

The assessment was made starting with the general and moving to the specific. There is a general set of codes and standards applicable to almost every facility designed and built in the United States. For instance, almost every facility will need provisions for its staff, and people need water in their day-to-day activities. Therefore, almost every facility will have piping designed and constructed to the provisions of the Uniform Plumbing Code. The specific effects of both the coupled nuclear reactor and the currently known characteristics of the production plant on the applicable codes and standards were then considered. Finally, permitting requirements were addressed.

The result of the assessment is a list of codes and standards that are expected to be applicable to the plant during its design and construction. The list is inclusive rather than exclusive. For instance, there are a number of piping codes that could be selected to govern the design and construction of piping. The majority of the commercial codes fall in the American Society of Mechanical Engineers (ASME) B31 code series (B31.3 being the most likely, but B31.1 could be selected, with B31.8 being the most likely code for a buried pipeline terminating at the plant). Other B31 codes may also be selected. This is indicated in the list with the entry "ASME B31 Series (B31.1, B31.3, and B31.8)".

\subsection{General Assessment}

A list of codes and standards generally applicable to the design and construction of any Department of Energy (DOE) facility, including the subject hydrogen production plant, was taken from the Idaho National Laboratory's (INLs) documentation supporting its design activities (STD-116, 2005). The list was revised to reflect the current status of the codes and standards and constitutes the majority of the codes and standards listed in this report. The list includes a substantial number of national codes and standards, and some references to the United States Code, the Code of Federal Regulations, Department of Energy, and lab-specific (Sandia, INL, and INEEL) documents.

The DOE and lab specific documents that appear in the list will be directly applicable to the plant only if the work is done by a DOE Laboratory. Should the work be contracted to an outside entity, the requirements of these documents will be incorporated in the contract documents, and the DOE and Lab specific documents themselves will not be an explicit part of the codes and standards to which the plant will be built.

The list is contained in Table 1, included at the end of this report. 


\subsection{Nuclear Assessment}

Federal law requires that the nuclear reactor associated with the hydrogen production plant be subjected to a Documented Safety Analysis (10 CFR 830, Subpart B). This process could have an effect on the codes and standards employed in the design of the hydrogen production plant ranging from minor to profound. An analysis has been undertaken to examine these potential impacts (Curtis Smith, Scott Beck, Bill Galyean, 2005). A number of design features have been identified that will minimize the effects of the nuclear requirements on the design of the hydrogen plant, provided that the loss of thermal efficiency resulting from imposing a blast-threat-reducing separation distance between reactor and production plant is acceptable. The design features discussed in the analysis include separation of hydrogen production from hydrogen storage areas, which may result in a design feature not commonly found at INL: a buried pipeline. The current code used for design and construction of a commercial buried hydrogen pipeline is ASME B31.8.

Should the separation distance yield unacceptable efficiencies, then changes in the hydrogen production plant design could include the addition of new systems, the replacement of commercial codes by their more strict nuclear counterparts, and the inclusion of codes specifying additional requirements for nuclear service. For example, the ASME B31 series (piping) and ASME Section VIII (pressure vessels) Codes could be replaced by their ASME Section III (Nuclear Components) counterparts. An example of additional nuclear requirements can be found in the qualification requirements for electrical equipment added by the Institute of Electrical and Electronics Engineers (IEEE) Standards 323, 344, 603, and 7-4.3.2 (IEEE Std 323-2003, IEEE Std 344-2004, and IEEE Std 603-1998). These codes represent imposition of additional design requirements and environmental and seismic testing requirements.

It is clear from this that an assessment of the codes and standards used in the design and construction of a hydrogen production plant cannot be undertaken without knowledge of the impact of a safety analysis of the associated nuclear reactor. Given that the results of the safety analysis are not available, the list presented here must be considered non-nuclear. This is true despite the fact that there are a small number of nuclear codes and standards in the list. These have been applied to the non-nuclear side because they have features attractive to the INL design community, and there are no equivalent documents on the non-nuclear side. For instance, AISC N690 is a nuclear code, but it offers structural provisions for stainless steel, which cannot be found on the commercial side, and hence is included in the list.

\subsection{Hydrogen Specific Assessment}

Two approaches were taken to assess the codes and standards applicable specifically to a hydrogen production plant, a web search and utilization of Applied Mechanics staff who actively participate in the Code writing activities of the ASME.

A web search was conducted using the proprietary IHS, Inc. web search capability ${ }^{\mathrm{a}}$ provided by the INL Technical Library. Searches using the keyword "hydrogen" yielded a number of codes and standards from the American Petroleum Institute (API), the Compressed Gas Association (CGA), and the American Institute of Aeronautics and Astronautics (AIAA). These were added to the list.

\footnotetext{
${ }^{\mathrm{a}} \mathrm{http}: / /$ www.ihs.com/
} 
Applied Mechanics staff participation in ASME Code writing activities ${ }^{b}$ has provided a perspective on the current industry approach to hydrogen production facility design. Hydrogen piping is typically designed to ASME B31.3 and vessels to ASME VIII. Materials known to be resistant to hydrogen embrittlement are used in the higher-pressure applications where this effect is enhanced. Persistent leakage of hydrogen is a given, hence dedicated ventilation systems are included to minimize any resulting problems. Head spaces are eliminated or vented, since free hydrogen rises in air. These discussions, while not directly linkable to codes or standards, do provide useful design information.

\subsection{Regulatory Assessment}

The primary drivers of permitting activities were taken from the INL instructions for performing environmental planning, compliance, and protection (LWP-8000), augmented by the list of codes and standards developed by the general assessment. These include:

- $\quad 40$ CFR 50-99 (Clean Air Act / Air Programs - CAA),

- $\quad 40$ CFR 100-149 (Clean Water Act / Water Programs - CWA),

- 40 CFR 260-299 (Resource Conservation Recovery Act - RCRA),

- $\quad 40$ CFR 300-349 (Comprehensive Environmental Response, Compensation, and Liability Act CERCLA),

- $\quad 40$ CFR 700-799 (Toxic Substance Control Act - TSCA), and

- $\quad 40$ CFR 1500-1599 (National Environment Policy Act - NEPA).

Of these, CRCLA and TSCA deal exclusively with legacy issues that are not applicable to a new facility and are not included in the list.

There will be related requirements made by the state in which the facility is to be built. For Idaho, the requirements are in IDAPA 58 (Department of Environmental Quality).

\subsection{Results}

Table 1 on page 5 lists the codes and standards applicable to a hydrogen production plant identified during this assessment. The list is inclusive rather than exclusive. While most of the codes and standards eventually used in the permitting, design, and construction of a plant will be found in the list, it is not anticipated that all entries will be used. The list is sorted by standard number. Dates of issue were not included, since the usual practice is to adopt the most current version at the time of design.

\footnotetext{
${ }^{\mathrm{b}}$ ASME B31.12 for hydrogen piping and pipelines and revision of ASME VIII for vessels (the pressure range is being extended to $15 \mathrm{ksi}$, primarily to accommodate high-pressure hydrogen storage).
} 


\section{References}

10 CFR 830, Subpart B, 2006, "Safety Basis Requirements," Code of Federal Regulations, Office of the Federal Register, January 2006.

Argonne National Laboratory - West, 2004, Balance of Plant Requirements for a Nuclear Hydrogen Pilot Plant, Rev. 0, ANL W7500-003-ES-00, September 2004.

Curtis Smith, Scott Beck, Bill Galyean, 2005, An Engineering Analysis for Separation Requirements of a Hydrogen Production Plant and High-Temperature Nuclear Reactor, INL/EXT-05-00137, Rev. 0, March 2005.

IEEE Std 323-2003, "IEEE Standard for Qualifying Class 1E Equipment for Nuclear Power Generating Stations," January 2004.

IEEE Std 344-2004, "IEEE Recommended Practice for Seismic Qualification of Class 1E Equipment for Nuclear Power Generating Stations," June 2005.

IEEE Std 603-1998, “IEEE Standard Criteria for Safety Systems for Nuclear Power Generating Stations," July 1998.

IEEE Std 7-4.3.2-2003, "IEEE Standard Criteria for Digital Computers in Safety Systems of Nuclear Power Generating Stations,” December 2003.

LWP-8000, 2005, "Environmental Instructions for Facilities, Processes, Materials and Equipment," September 2005.

STD-116, 2005, “INEEL Architectural Engineering Standards," Revision 31, March 8, 2005.

Ward, Bradley, 2006, Balance of Plant Requirements for a Nuclear Hydrogen Plant, INL/EXT-0611232, Rev. 1, April 2006. 
Table 1. List of codes and standards applicable to a hydrogen production plant coupled to a nuclear reactor.

\begin{tabular}{|c|c|}
\hline Number & Title \\
\hline 10 CFR 435 & Energy Conservation Performance Standards for New Buildings \\
\hline 29 CFR 1910 & Occupational Safety and Health Standards (OSHA) \\
\hline 29 CFR 1926 & Safety and Health Regulations for Construction \\
\hline 40 CFR 100-149 & Clean Water Act / Water Programs (CWA) \\
\hline 40 CFR 1500-1599 & National Environment Policy Act (NEPA) \\
\hline 40 CFR 260-299 & Resource Conservation Recovery Act (RCRA) \\
\hline 40 CFR 50-99 & Clean Air Act / Air Programs (CAA) \\
\hline 40 CFR 700-799 & Toxic Substance Control Act (TSCA) \\
\hline AASHTO & Standard Specifications for Highway Bridges \\
\hline ACGIH & Industrial Ventilation Manual of Recommended Practice \\
\hline AIAA G-109 & $\begin{array}{l}\text { Guide to Safety of Hydrogen and Hydrogen Systems (American Institute of } \\
\text { Aeronautics and Astronautics) }\end{array}$ \\
\hline AISC ASD & $\begin{array}{l}\text { Specifications for Structural Steel Buildings, Allowable Stress Design, Plastic } \\
\text { Design }\end{array}$ \\
\hline AISC LRFD & $\begin{array}{l}\text { Load and Resistance Factor Design Specification for Structural Steel } \\
\text { Buildings }\end{array}$ \\
\hline AISC N690 & $\begin{array}{l}\text { Nuclear Facilities: Steel Safety-Related Structures for Design, Fabrication } \\
\text { and Erection }\end{array}$ \\
\hline AISI & Specification for the Design of Cold-Formed Steel Structural Members \\
\hline ANSI A117.1 & $\begin{array}{l}\text { Specifications for Making Buildings and Facilities Accessible to and Usable } \\
\text { by Physically Handicapped People }\end{array}$ \\
\hline ANSI A156 Series & Door and Window Hardware \\
\hline ANSI A250.8 & Recommended Specifications for Standard Steel Doors and Frames \\
\hline ANSI B30.16 & Overhead Hoists (Underhung) \\
\hline ANSI C2 & National Electrical Safety Code (NESC)+B186 \\
\hline ANSI S3.5 & Methods of Calculations of the Speech Intelligibility Index \\
\hline ANSI/NB-23 & National Board Inspection Code \\
\hline API & American Petroleum Institute Guidelines \\
\hline API RP $(500,505,941)$ & $\begin{array}{l}\text { Recommended Practice for Classification of Locations for Electrical } \\
\text { Installations at Petroleum Facilities Classified as Class I, Division } 1 \text { and } \\
\text { Division } 2\end{array}$ \\
\hline ARMA & $\begin{array}{l}\text { Guide to Preparing Built-Up Roofing (BUR) Specifications, Recommended } \\
\text { Performance Criteria for Roofing Membranes using Polymer Modified } \\
\text { Bituminous Products }\end{array}$ \\
\hline ASCE 7 & Minimum Design Loads for Buildings and Other Structures \\
\hline ASHRAE Standard 100 & Energy Conservation in Existing Buildings \\
\hline ASME (II, III, IVIII, IX) & ASME Boiler and Pressure Vessel Codes \\
\hline ASME B1 Series & Threads \\
\hline ASME B16 Series & Fittings, Flanges, Valves and Gaskets \\
\hline ASME B30.2 & Overhead and Gantry Cranes \\
\hline $\begin{array}{l}\text { ASME B31 Series } \\
\text { (B31.1, B31.3, B31.8, } \\
\text { B31.9) }\end{array}$ & ASME Piping Codes \\
\hline ASME B36 Series & Pipe and Tubes \\
\hline ASTM A795 & $\begin{array}{l}\text { Standard Specification for Black and Hot-Dipped Zinc-Coated (Galvanized) } \\
\text { Welded and Seamless Steel Pipe for Fire Protection Use }\end{array}$ \\
\hline ASTM Series & Material and Product Standards \\
\hline
\end{tabular}




\begin{tabular}{|c|c|}
\hline Number & Title \\
\hline AWS (D1.1) & American Welding Society Welding Codes \\
\hline AWWA & American Water Works Association Standards \\
\hline CGA G-4.1 & Cleaning Equipment for Oxygen Service, 1996. \\
\hline CGA G-5.5 & Hydrogen Vent Systems, 1996. \\
\hline CMAA 70 & Specification for Electric Overhead Traveling Cranes \\
\hline CMAA 74 & $\begin{array}{l}\text { Specification for Top Running and Under Running Single Girder Electric } \\
\text { Overhead Traveling Cranes }\end{array}$ \\
\hline DCID 1/21 & Director of Central Intelligence Directive 07/94 \\
\hline DOD & $\begin{array}{l}\text { Interim DOD Anti-Terrorism Force Protection Construction Standards } \\
\text { Code }\end{array}$ \\
\hline DOE 251.9 & Security Requirements for Classified Automatic Data Processing \\
\hline DOE 421.2A & Classified Automated Information System Security Program \\
\hline DOE 5632.1C & Protection and Control of Safeguards and Security Interests \\
\hline DOE CG-SS-3 & DOE Classification Guide CG-SS-3 \\
\hline DOE G 420.1-1 & Nonreactor Nuclear Safety Design and Explosives Safety Criteria \\
\hline DOE G 420.1-2 & $\begin{array}{l}\text { Guide for the Mitigation of Natural Phenomena Hazards for DOE Nuclear } \\
\text { Facilities and Nonnuclear Facilities }\end{array}$ \\
\hline DOE G 420.1X & $\begin{array}{l}\text { Implementation Guide for Nonreactor Nuclear Safety Design Criteria and } \\
\text { Explosives Safety Criteria }\end{array}$ \\
\hline DOE ID N 430.1A & Life Cycle Asset Management : ID Expectations \\
\hline DOE M 200.1-1 & Telecommunications Security Manual \\
\hline DOE M 440.1-1 & DOE Explosive Safety Manual \\
\hline DOE M 471.2-1B, -1C & Classified Matter Protection and Control Manual \\
\hline DOE M 471.2A & Technical Surveillance Countermeasures \\
\hline DOE M 471.2B & Information Security Program \\
\hline DOE M 5632.1C-1 & Manual for Protection and Control of Safeguards and Security Interests \\
\hline DOE N 2051 & Unclassified Computer Security Program \\
\hline DOE O 413.3 & Project Management \\
\hline DOE O 420.1 & Facility Safety \\
\hline DOE O 430.1 & Life Cycle Asset Management \\
\hline DOE O 430.2 & In House Energy Management \\
\hline DOE O 440.1 & $\begin{array}{l}\text { Worker Protection Management for DOE Federal and Contractor } \\
\text { Employees }\end{array}$ \\
\hline DOE O 473.1 & Protection and Control of Safeguards and Security Interests \\
\hline DOE/ID-10425 & $\begin{array}{l}\text { Storm Water Pollution Prevention Plan for Construction Activities - } \\
\text { Generic Plan }\end{array}$ \\
\hline DOE-HDBK-1062 & DOE Fire Protection Handbook \\
\hline DOE-STD-1020 & $\begin{array}{l}\text { Natural Phenomena Hazards Design and Evaluation Criteria for DOE } \\
\text { Facilities }\end{array}$ \\
\hline DOE-STD-1021 & $\begin{array}{l}\text { Natural Phenomena Hazards Performance Categorization Guidelines for } \\
\text { Structures, Systems, and Components }\end{array}$ \\
\hline DOE-STD-1031 & Guide to Good Practices for Communications \\
\hline DOE-STD-1042 & Guide to Good Practices for Control Area Activities \\
\hline DOE-STD-1066 & Fire Protection Design Criteria \\
\hline DOE-STD-1088 & Fire Protection for Relocatable Structures \\
\hline DOE-STD-1090 & Hoisting and Rigging \\
\hline DOE-STD-3003 & Backup Power Sources for DOE Facilities \\
\hline EJMA & Expansion Joint Manufacturers' Association Standards \\
\hline
\end{tabular}




\begin{tabular}{|c|c|}
\hline Number & Title \\
\hline FM & Factory Mutual Approval Guide \\
\hline $\begin{array}{l}\text { FM ( 1-28, 1-28S, 1-54, 1- } \\
57,3-2,3-3,3-7 N, 3-10)\end{array}$ & Factory Mutual Loss Prevention Data Sheets \\
\hline IBC & International Building Code (IBC) \\
\hline ICEA & ICEA Standards \\
\hline $\begin{array}{l}\text { Idaho Code,Title1, Chapter } \\
2\end{array}$ & $\begin{array}{l}\text { Idaho Water Quality Standards and Waste Water Treatment } \\
\text { Requirements }\end{array}$ \\
\hline IDAPA 37.03 .09 & $\begin{array}{l}\text { Well Construction Standards Rules, State of Idaho Dept of Water } \\
\text { Resources }\end{array}$ \\
\hline IDAPA 58.01 .08 & $\begin{array}{l}\text { Idaho Rules for Public Drinking Water Systems, State of Idaho Dept of } \\
\text { Environmental Quality }\end{array}$ \\
\hline IEEE 142 & Grounding of Industrial and Commercial Power Systems \\
\hline IEEE 242 & $\begin{array}{l}\text { Recommended Practice for Protection and Coordination of Industrial and } \\
\text { Commercial Power Systems }\end{array}$ \\
\hline IEEE 315, 315A & Graphic Symbols for Electrical and Electronics Diagrams \\
\hline IEEE 399 & Recommended Practice for Power Systems Analysis \\
\hline IEEE 484 & $\begin{array}{l}\text { Recommended Practice for Design and Installation of Large Lead } \\
\text { Storage Batteries for Generating Stations and Substations }\end{array}$ \\
\hline IEEE 493 & $\begin{array}{l}\text { Recommended Practice for Design of Reliable Industrial and Commercial } \\
\text { Power Systems }\end{array}$ \\
\hline IEEE 576 & $\begin{array}{l}\text { Recommended Practice for Installation, Termination, and Testing of } \\
\text { Insulated Power Cable as Used in the Petroleum and Chemical Industry }\end{array}$ \\
\hline IEEE 80 & Safety in AC Substation Grounding \\
\hline IEEE C37 series & Circuit Breakers, Switchgear, Relays, Substations and Fuses \\
\hline IES & IES Lighting Handbook \\
\hline IFC & International Fire Code \\
\hline IMC & IAPMO/ICBO International Mechanical Code \\
\hline IPC & International Plumbing Code IAPMO \\
\hline ISA & ISA Standards \\
\hline ISA RP-60 & Electrical Guide for Control Centers Recommended Practice \\
\hline ISDSI 102 & Installation Standard for Insulated Steel Door Systems \\
\hline MBMA & Metal Buildings Systems Manual \\
\hline MSS & $\begin{array}{l}\text { Manufacturers Standardization Society Valve, Fitting and Hanger } \\
\text { Standards }\end{array}$ \\
\hline NAVFAC DM-4.9 & $\begin{array}{l}\text { Naval Facilities Engineering Command Design Manual "Energy } \\
\text { Monitoring and Control Systems" }\end{array}$ \\
\hline NBS 135 & Life Cycle Cost Manual for Federal Energy Management Programs \\
\hline NEMA & NEMA standards \\
\hline NFPA & National Fire Protection Association (NFPA) Codes and Standards \\
\hline NFPA 10 & Portable Fire Extinguishers \\
\hline NFPA 101 & Life Safety Code \\
\hline NFPA 101A & Alternative Approaches to Life Safety \\
\hline NFPA 110 & Emergency and Standby Power Systems \\
\hline NFPA 12 & Standard on Carbon Dioxide Extinguishing Systems \\
\hline NFPA 13 & Installation of Sprinkler Systems \\
\hline NFPA 20 & Installation of Centrifugal Fire Pumps \\
\hline NFPA 22 & Water Tanks for Private Fire Protection \\
\hline NFPA 24 & Installation of Private Fire Service Mains and Their Appurtenances \\
\hline NFPA 30 & Flammable and Combustible Liquids Code \\
\hline
\end{tabular}




\begin{tabular}{|c|c|}
\hline Number & Title \\
\hline NFPA 31 & Oil-Burning Equipment \\
\hline $\begin{array}{l}\text { NFPA 54/ANSI } \\
\text { Z+A128223.1 }\end{array}$ & National Fuel Gas Code \\
\hline NFPA 58 & Standard for the Storage and Handling of Liquefied Petroleum Gases \\
\hline NFPA 70 & National Electrical Code \\
\hline NFPA 72 & National Fire Alarm Code \\
\hline NFPA 75 & $\begin{array}{l}\text { Standard for the Protection of Electronic Computer/Data Processing } \\
\text { Equipment }\end{array}$ \\
\hline NFPA 780 & Standard for the Installation of Lighting Protection System \\
\hline NFPA 79 & Industrial Machinery \\
\hline NFPA 80 & Fire Doors and Windows \\
\hline NFPA $90 A$ & Installation of Air Conditioning and Ventilating Systems \\
\hline NFPA 90B & Installation of Warm Air Heating and Air Conditioning Systems \\
\hline NFPA Codes & Codes applicable to special occupancies or materials \\
\hline NISP & National Industrial Security Program \\
\hline NISPOM & National Industrial Security Program Operating Manual \\
\hline NRCA & $\begin{array}{l}\text { Roofing and Waterproofing Manual, Handbook of Accepted Roofing } \\
\text { Knowledge }\end{array}$ \\
\hline NSF & National Sanitation Foundation Listings \\
\hline REA Bulletin 50-1 & Standard T-805B \\
\hline REA Bulletin 50-3 & Standard D-804 \\
\hline REA Bulletin 50-6 & Standard D-806 \\
\hline SAND 87-1926 & Access Delay Technology Transfer Manual (UNCI) \\
\hline SAND 99-2388 & Interior Intrusion Detection, DOE-OSS (UNCI) \\
\hline SAND 99-2389 & Video Assessment, DOE-OSS UNCI \\
\hline SAND 99-2390 & Alarm Communications and Display DOE-OSS UNCI \\
\hline SAND 99-2391 & Exterior Intrusion Detection, DOE-OSS UNCI \\
\hline SAND 99-2392 & Protecting Security Communications DOE-OSS UNCI \\
\hline SAND 99-2486 & Explosives Protection, DOE-OSS UNCI \\
\hline SDI & Design Manual for Composite Decks, Form Decks and Roof Decks \\
\hline SDI 108 & Selection and Usage Guide for Standard Steel Doors \\
\hline SJI & Standard Specification for Open Web Steel Joists \\
\hline SMACNA & Architectural Sheet Metal Manual \\
\hline SPRI & Professional Guide to Specifications, Parts I-IV Wind Design. \\
\hline TR 15916 & Basic considerations for the safety of hydrogen systems \\
\hline UBC & Uniform Building Code \\
\hline UL & $\begin{array}{l}\text { Product Directories of Underwriters' Laboratories, together with the } \\
\text { periodic supplements (UL) }\end{array}$ \\
\hline UL 1034 & Burglary Resistant Electric Locking Mechanisms \\
\hline UL 1076 & Proprietary Burglar Alarm Units and Systems \\
\hline UL 13 & Power Limited Circuit Cable \\
\hline UL 1610 & Central Station Burglar Alarm Units \\
\hline UL 1651 & Optical Fiber Cable \\
\hline UL 1778 & Uninterruptible Power Supply Equipment \\
\hline UL 294 & Access Control system Units \\
\hline UL 3044 & Surveillance Closed Circuit Television Equipment \\
\hline UL 365 & Police Station Connected Burglar Alarm Units and Systems \\
\hline UL 444 & Communications Cables \\
\hline
\end{tabular}




\begin{tabular}{|l|l|}
\hline \multicolumn{1}{|c|}{ Table 1 (continued). } & \\
\hline UL 452 & Antenna Discharge Units \\
\hline UL 497 & Protectors for Paired Conductor Communications Circuits \\
\hline UL 497B & Protectors for DATA Communications and Fire Alarms Circuits \\
\hline UL 603 & Power Supplies for use with Burglar Alarm Systems \\
\hline UL 609 & Local Burglar Alarm Units and Systems \\
\hline UL 636 & Holdup Alarm Units and Systems \\
\hline UL 639 & Intrusion Detection Units \\
\hline UL 681 & Installation and Classification of Burglar and Holdup Alarm Systems \\
\hline UL 827 & Central Station Alarm Service \\
\hline UL 900 & Test Performance of Air Filter Units \\
\hline UL 96 & Lightning Protection Components \\
\hline UL 983 & Surveillance Camera Units \\
\hline & $\begin{array}{l}\text { Recommended Standards for Wastewater Facilities, Great Lakes-Upper } \\
\text { Mississippi River Board of State Public Health and Environmental } \\
\text { Managers }\end{array}$ \\
\hline & $\begin{array}{l}\text { State of Idaho Transportation Dept, Division of Highways, Standard } \\
\text { Specifications for Highway Construction }\end{array}$ \\
\hline & U.S. DOE Security Container and Locking Device Guide \\
\hline & Union Pacific Railroad, Technical Specifications for Industrial Tracks \\
\hline
\end{tabular}

